\title{
Kinetic and Adsorption Study for Removal of Arsenic from Aqueous Medium by Low Cost Bentonite of Rajmahal Hills and Hazaribagh, Jharkhand
}

\author{
Sourav Majumder*†, Ashok Kr. Jha** \\ *Department of Chemistry,Kaliachak College,University of Gour Banga, Malda-732101, West Bengal, India \\ **University Department of Chemistry, T.M.B.U, Bhagalpur-812007, Bihar, India \\ †Corresponding author: Sourav Majumder; bantimajumder82@gmail.com
}

Nat. Env. \& Poll. Tech.

Website: www.neptjournal.com

Received: 01-11-2019

Revised: 29-11-2019

Accepted: $31-01-2020$

Key Words:

Bentonite

Arsenite

Chemical kinetics

Adsorption

\begin{abstract}
The paper deals with the feasibility of arsenite removal by the adsorption from bentonite mineral. Groundwater arsenic contamination has been reported in different parts of the world including Jharkhand, Bihar and Uttar Pradesh. Tube wells in Holocene Newer Alluvium are characterized by grey to black coloured organic-rich argillaceous sediments which have arsenic-contaminated groundwater. The majority of arsenic present in the groundwater is in the form of As(III) which exists as uncharged species arsenic tri hydroxide at $\mathrm{pH}$ value of less than 9.2. Arsenite is removed by various techniques like coagulation microfiltration, fixed bed adsorption, bioremoval, ion exchange, membrane filtration, etc. Our studies have shown that locally available bentonites containing a unit of montmorillonites can remove the arsenic from an aqueous medium. On the treatment of $100 \mathrm{~mL}$ arsenite solution with 300 mesh sieves bentonites up to different intervals of time, it has been found that bentonites are good adsorbent of arsenite. The percentage removal of arsenite is up to 99 per cent with $3 \mathrm{~g}$ sodium derivative of bentonite for 1 hour. The removal efficiency, adsorption isotherm and kinetic studies show the suitability of bentonite minerals for arsenic removal following first-order kinetics. Freundlich and Langmuir isotherms are obeyed in the adsorption of arsenite by bentonite minerals. Adsorption of arsenic by bentonite minerals has proved to be a low-cost eco-friendly method. Sodium derivative of bentonite minerals has been found more efficient for removal of arsenite.
\end{abstract}

\section{INTRODUCTION}

Arsenic contamination of drinking water has become a matter of worldwide concern. Main causes of occurrence of arsenic in groundwater may be attributed to pyrite bearing shale, As-Cu mineralization and Gold belt of the Son valley with arsenic content. Arsenic problem is not only local and national but also global. The danger of arsenic contaminating the water reserves in the entire world is on the rise. Most water enters from natural deposits in the earth. Arsenic occurs as arsenic sulphide minerals like arsenopyrites (Jha 2016, Jha 2018). Some of the arsenic impurities exist in calcium carbonate and phosphate minerals where it substitutes for carbonate and phosphate. In oxidizing soils arsenate is bound to ferric hydroxide minerals such as ferrihydrite and haematite (Mermut 1994, Brindley 1980). Organic matter converts ferric to more soluble ferrous, in effect dissolving arsenic and causing an increase in arsenic in ground level. Use of arsenical pesticides, herbicides, industrial and agricultural pollution increases the arsenic level in groundwater (Jha et al. 2011, Jha et al. 2010). Inorganic arsenicals are more toxic than organic arsenicals. As(III) is more toxic than As(V) ( Jha \& Mishra 2012, Lagaly 1995)
Arsenite exists in aqueous medium as $\mathrm{H}_{2} \mathrm{AsO}_{3}$ and $\mathrm{H}_{3} \mathrm{AsO}_{3}$ whereas arsenate is as $\mathrm{HAsO}_{4}^{2-}$ and $\mathrm{H}_{2} \mathrm{AsO}_{4}^{2-}$. An alarming aspect of arsenic-contaminated groundwater is in its use of irrigating crops and vegetables to which arsenic passes and then consumed by humans.

Bentonites in different colours and grades are available in many states of the country. Rajmahal hill bentonites have been found as good quality bentonites due to their cation exchange capacity, swelling power and potential for adsorption. Hazaribagh bentonites have not been analysed for physicochemical characteristics and removal capacity of arsenic and heavy metals till date. The bentonites minerals containing montmorillonite unit having a negative charge which is balanced by the cations held on the surface. It has been established that the structure of Bentonite is 2:1 which implies that one octahedral sheet is sandwiched between two tetrahedral sheets (Guyonnet et al. 2005, Bailey 1982). The bentonites have a cation exchange capacity varying from 70 to $110 \mathrm{meq} / 100 \mathrm{~g}$ of clay due to exchangeable cations such as $\mathrm{Na}^{+}, \mathrm{Ca}^{+2}$ and $\mathrm{Mg}^{+2}$.

The cation exchange capacity may be represented as:

$$
\mathrm{BH}+\mathrm{M}^{+}=\mathrm{BM}+\mathrm{H}^{+}
$$


Where, $\mathrm{M}^{+}$represents a cation, $\mathrm{H}^{+}$is a cation. $\mathrm{M}^{+}$ exchange $\mathrm{H}^{+}$cation and $\mathrm{BH}$ is an exchanger.

$$
\mathrm{K}=[\mathrm{BM}]\left[\mathrm{H}^{+}\right] /[\mathrm{BH}]\left[\mathrm{M}^{+}\right]
$$

Where, $\mathrm{K}$ is the thermodynamic equilibrium constant.

The molecular formula of Bentonite is $(\mathrm{Na}, \mathrm{Ca})_{0.33}$, (Al, Mg) ${ }_{2}, \mathrm{Si}_{4} \mathrm{O}_{10}(\mathrm{OH})_{2} \cdot \mathrm{n}_{2} \mathrm{O}$. The main constituent of this smectite clay mineral is silica and alumina (Brindley et al. 1986). In addition to this calcium oxide, sodium oxide, magnesium oxide, ferrous oxide/ferric oxide and traces of titanium oxide are present. Arsenic removal of water or prepared synthetic samples takes place both by ion exchange and the surface area of bentonites available for adsorption (Calvert 1981). This is the explanation commonly offered by research workers on arsenic. The pure sample, as well as derivatives of the collected bentonites from different places of Hazaribagh and Rajmahal Hills, have been analysed for arsenic removal capacity. The effect of contact time with a fixed mass of montmorillonite in $100 \mathrm{~mL}$ solution of sodium arsenite has been studied. The adsorption mechanism has been explained by Freundlich Adsorption Isotherm, given as

$$
\mathrm{q}_{\mathrm{c}}=\mathrm{K} \cdot \mathrm{C}^{1 / \mathrm{n}} \text { or } \mathrm{x} / \mathrm{m}=\mathrm{K} \cdot \mathrm{C}^{1 / \mathrm{n}}
$$

Where, $\mathrm{x} / \mathrm{m}$ is the mass of adsorbate per unit adsorbent.

$$
\log \mathrm{x} / \mathrm{m}=\log \mathrm{K}+1 / \mathrm{n} \log \mathrm{C}
$$

The value of $\mathrm{K}$ and $1 / \mathrm{n}$ are obtained from the intercept and slope respectively (Karthikeyan et al. 2005, Jha 2012).

The value of $\mathrm{x} / \mathrm{m}$ or $\mathrm{q}_{\mathrm{c}}$ is obtained from the formula given below.

$$
\mathrm{q}_{\mathrm{c}}=\left[\left(\mathrm{C}_{0}-\mathrm{Ce}\right) \times \mathrm{V}\right] / \mathrm{w}
$$

Where, $\mathrm{C}_{0}$ and $\mathrm{Ce}$ are the initial and equilibrium concentrations of arsenite respectively. $\mathrm{W}$ is the mass of adsorbent and $\mathrm{V}$, the volume of solution being used. The percentage removal is given by:

$$
\% \text { removal }=\left[\left(\mathrm{C}_{0}-\mathrm{Ct}\right) / \mathrm{C}_{0}\right] \times 100
$$

If a straight line is obtained in the plot of $q_{t} / c t$ vs. $c_{t}$, Langmuir model is followed and a straight line obtained between a graph of $\log \mathrm{x} / \mathrm{m}$ and $\log \mathrm{C}$ confirms Freundlich isotherm.

\section{MATERIALS AND METHODS}

The bentonite minerals were collected from the different sampling sites of Hazaribagh districts mainly located at lat. $23.99^{\circ} \mathrm{N}$ and long. $85.37^{\circ} \mathrm{E}$. The places are Barhi (Kundba), Barkagaon (Debgarh), Chauparan (Chandpur), Chalkusha (Sudan), Barkatha (Shiladhi), Keredari (Masuria), Churchu (Sandi), Karbekla (Kesu) and Oriya (Rolagaon). The samples were finely powdered up to 300 mesh sieve. The sample which gave blue colour with benzidine solution indicates the presence of montmorillonite unit. The stock solution of $100 \mathrm{ppm}$ arsenite solution was prepared by dissolving 173.5 $\mathrm{mg}$ of anhydrous sodium arsenite of analytical grade in $1 \mathrm{~L}$ distilled water. Two ppm solution of arsenite was prepared by dilution of the stock solution. All the glassware were washed with dilute acid and then washed with double distilled water. $100 \mathrm{~mL} 2 \mathrm{ppm}$ solution was taken in $250 \mathrm{~mL}$ conical flask and $1 \mathrm{~g}$ bentonite sample was added to the conical flask and suspension was shaken in a mechanical shaker up to a different interval of time (ranging from 1 hour to 3 hours). This process was repeated with different masses of bentonite samples viz. $1 \mathrm{~g}, 2 \mathrm{~g}, 3 \mathrm{~g}$ up to $1 \mathrm{hr}$. After the shaking was over the solution was filtered with filter paper Whatman filter paper No. 42. The residual concentration of the arsenite ion was estimated by Mercko quant Arsenic Kit available in the laboratory. $5 \mathrm{~mL}$ test solution is taken in which reagent I is added and when this dissolves completely, reagent II is added. The strip supplied by the company is inserted into the tube up to 20 minutes. Special care is taken so that the strip might not come in contact with the test solution. After 20 minutes the strip is taken out and matched with the intensity of the colour. This gives the range of arsenic from $0.02 \mathrm{ppm}$ to $2 \mathrm{ppm}$ and more. Arsenic content was analysed by atomic absorption spectrophotometer also. The results obtained by the kit agree with the results obtained from the atomic absorption spectrophotometer (Perkin Elmer). The experiments were carried out in a neutral medium. The rate constant was calculated using the rate equation (Ramesh et al. 2007). The adsorbate per unit adsorbent values was put in the equation and tested for Freundlich and Langmuir isotherms (Sharma et al. 1995, J. Md. et al. 2008, Mondal et al. 2006, Dai et al. 1993)

\section{RESULTS AND DISCUSSION}

From Table 1, it is clear that the maximum removal of arsenite takes place with sample $\mathrm{S}_{6}$ (2540) after treatment of $100 \mathrm{~mL} 2 \mathrm{ppm}$ arsenic (III) solution (Haque et al. 2008, Maiti et al. 2007)

The Effect of contact time and adsorbent dosage has been studied with different grades of pure bentonite samples and their derivatives (Deliyanni et al. 2007, Ersoy et al. 2003). The initial concentration of arsenic decreases up to $0.2 \mathrm{ppm}$ when $100 \mathrm{~mL} 2 \mathrm{ppm}$ sodium arsenite solution is treated with either $2 \mathrm{~g}, 3 \mathrm{~g}$ bentonite up to 1 hour, the residual concentrations after 1 hour are $0.3 \mathrm{ppm}, 1.2 \mathrm{ppm}$ and $0.6 \mathrm{ppm}$ respectively, when treated with pure samples of bentonite $\mathrm{S}_{6}(2540), \mathrm{S}_{7}(2541)$ and $\mathrm{S}_{20}(2542)$ (Tables $\left.1 \& 2\right)$ ). After 2 hours of treatment, the concentration decreases up to $0.2 \mathrm{ppm}$ (Tables $1 \& 4$ ) but the maximum removal takes place after 3 hours with sodium derivative of $\mathrm{S}_{6}(2540)$ (Table 5). When 
Table 1: Concentration of arsenic (III) ion after treatment with $1 \mathrm{~g}$ of bentonite mineral.

\begin{tabular}{|llllll|}
\hline Sl. No. & Bentonite Sample No. & $\begin{array}{l}\text { Initial concentration of } \\
\text { arsenic(III)ion (in ppm) }\end{array}$ & $\begin{array}{l}\text { Residual concentration } \\
\text { after 1 hour. (in ppm) }\end{array}$ & $\begin{array}{l}\text { Residual concentration } \\
\text { after 2 hours (in ppm) }\end{array}$ & $\begin{array}{l}\text { Residual concentration } \\
\text { after 3 hours (in ppm) }\end{array}$ \\
\hline 1 & $\mathrm{~S}_{6}(2540)$ & 2 & 0.3 & 0.2 & 0.2 \\
2 & $\mathrm{~S}_{7}(2541)$ & 2 & 1.2 & 0.8 & 0.6 \\
3 & $\mathrm{~S}_{20}(2542)$ & 2 & 0.6 & 0.4 & 0.3 \\
4 & Na Derivative of $\mathrm{S}_{6}(2540)$ & 2 & 0.825 & 0.737 & 0.4 \\
5 & Na Derivative of $\mathrm{S}_{7}(2541)$ & 2 & 0.612 & 0.523 & 0.413 \\
\hline
\end{tabular}

Table 2: Concentration of arsenic (III) ion after treatment with different masses of bentonite mineral.

\begin{tabular}{|llllll|}
\hline S1.No & Bentonite Sample No. & $\begin{array}{l}\text { Initial concentration } \\
\text { of arsenic(III) ion } \\
(\mathrm{ppm})\end{array}$ & $\begin{array}{l}\text { Residual concentration } \\
\text { with 1 g bentonite } \\
\text { treatment after 1 hour } \\
(\mathrm{ppm})\end{array}$ & $\begin{array}{l}\text { Residual concentration } \\
\text { with 2 g bentonite } \\
\text { treatment after 1 hour } \\
(\mathrm{ppm})\end{array}$ & $\begin{array}{l}\text { Residual concentration } \\
\text { with } 3 \mathrm{~g} \text { bentonite } \\
\text { treatment after 1hour } \\
(\mathrm{ppm})\end{array}$ \\
\hline 1 & $\mathrm{~S}_{6}(2540)$ & 2 & 0.3 & 0.2 & 0.2 \\
2 & $\mathrm{~S}_{7}(2541)$ & 2 & 1.2 & 0.6 & 0.05 \\
3 & $\mathrm{~S}_{20}(2542)$ & 2 & 0.6 & 0.4 & 0.2 \\
4 & Na Derivative of $\mathrm{S}_{6}(2540)$ & 2 & 0.825 & 0.4 & 0.02 \\
5 & Na Derivative of $\mathrm{S}_{7}(2541)$ & 2 & 0.612 & 0.571 & 0.327 \\
\hline
\end{tabular}

Table 3: Percentage arsenic removal after treatment with $1 \mathrm{~g}$ of bentonite mineral for 1 hour and values of $\mathrm{q}_{\mathrm{t}}, \mathrm{C}_{\mathrm{t}}, \log \mathrm{qt}$ and $\log \mathrm{Ct}$.

\begin{tabular}{|lllllll|}
\hline S1.No & Bentonite Sample No. & $\%$ Removal & $\mathrm{q}_{\mathrm{t}}$ & $\mathrm{C}_{\mathrm{t}}$ & $\log \mathrm{q}_{\mathrm{t}}$ \\
\hline 1 & $\mathrm{~S}_{6}(2540)$ & 85 & 170 & 0.3 & 2.230 & -0.5228 \\
2 & $\mathrm{~S}_{7}(2541)$ & 40 & 80 & 1.2 & 1.903 & -0.0791 \\
3 & $\mathrm{~S}_{20}(2542)$ & 70 & 140 & 0.6 & 2.146 & -0.2218 \\
4 & Na Derivative of $\mathrm{S}_{6}(2540)$ & 58.75 & 117.5 & 0.825 & -0.070 & -0.0835 \\
5 & Na Derivative of $\mathrm{S}_{7}(2541)$ & 69.4 & 138.8 & 0.612 & 1.841 \\
\hline
\end{tabular}

Table 4: Percentage arsenite removal after treatment with $1 \mathrm{~g}$ of bentonite mineral for 2 hour and values of $\mathrm{q}_{\mathrm{t}}, \mathrm{C}_{\mathrm{t}}, \log \mathrm{qt}$ and $\log \mathrm{Ct}$.

\begin{tabular}{|lllllll|}
\hline Sl.No & Bentonite Sample No. & \% Removal & $\mathrm{q}_{\mathrm{t}}$ & $\mathrm{C}_{\mathrm{t}}$ & $\log \mathrm{q}_{\mathrm{t}}$ \\
\hline 1 & $\mathrm{~S}_{6}(2540)$ & 90 & 180 & 0.2 & 2.2550 & -0.6989 \\
2 & $\mathrm{~S}_{7}(2541)$ & 60 & 120 & 0.8 & 1.7780 & -0.0969 \\
3 & $\mathrm{~S}_{20}(2542)$ & 80 & 160 & 0.4 & 1.9030 & -0.3979 \\
4 & Na Derivative of $\mathrm{S}_{6}(2540)$ & 63.15 & 126.3 & 0.737 & -0.1325 \\
5 & Na Derivative of $\mathrm{S}_{7}(2541)$ & 73.85 & 147.7 & 0.523 & 2.1694 \\
\hline
\end{tabular}

Table 5: Percentage arsenite removal after treatment with $1 \mathrm{~g}$ of bentonite mineral for 3 hours and values of $\mathrm{q}_{\mathrm{t}}, \mathrm{C}_{\mathrm{t}}, \log \mathrm{qt}$ and $\log \mathrm{Ct}$.

\begin{tabular}{|lllllll|}
\hline Sl.No & Bentonite Sample No. & $\%$ Removal & $\mathrm{q}_{\mathrm{t}}$ & $\mathrm{C}_{\mathrm{t}}$ & $\log \mathrm{q}_{\mathrm{t}}$ \\
\hline 1 & $\mathrm{~S}_{6}(2540)$ & 90 & 180 & 0.2 & 2.2552 & -0.6989 \\
2 & $\mathrm{~S}_{7}(2541)$ & 70 & 140 & 0.6 & 2.1461 & -0.2218 \\
3 & $\mathrm{~S}_{20}(2542)$ & 85 & 170 & 0.3 & 2.2304 & -0.5228 \\
4 & Na Derivative of $\mathrm{S}_{6}(2540)$ & 80 & 160 & 0.4 & 2.204 & -0.3979 \\
5 & Na Derivative of $\mathrm{S}_{7}(2541)$ & 79.35 & 158.70 & 0.413 & 1.8995 \\
\hline
\end{tabular}

Table 6: Per cent arsenic removal after treatment with $2 \mathrm{~g}$ of bentonite mineral for 1 hour and values of $\mathrm{q}_{\mathrm{t}}, \mathrm{C}_{\mathrm{t}}, \log \mathrm{qt}$ and $\log \mathrm{Ct}$.

\begin{tabular}{|lllllll|}
\hline Sl.No. & BentoniteSample No. & \%Removal & $\mathrm{q}_{\mathrm{t}}$ & $\mathrm{C}_{\mathrm{t}}$ & $\log \mathrm{q}_{\mathrm{t}}$ \\
\hline 1 & $\mathrm{~S}_{6}(2540)$ & 90 & 90 & 0.2 & 1.9542 & -0.6989 \\
2 & $\mathrm{~S}_{7}(2541)$ & 70 & 70 & 0.6 & 1.8450 & -0.2218 \\
3 & $\mathrm{~S}_{20}(2542)$ & 80 & 80 & 0.4 & 1.9030 & -0.3979 \\
4 & Na Derivative of $\mathrm{S}_{6}(2540)$ & 80 & 80 & 0.4 & 1.9030 & -0.3979 \\
5 & Na Derivative of $\mathrm{S}_{7}(2541)$ & 71.45 & 71.45 & 0.571 & 1.8540 \\
\hline
\end{tabular}


Table 7: Percentage arsenic removal after treatment with $3 \mathrm{~g}$ of bentonite mineral for 1 hour and values of $\mathrm{q}_{\mathrm{t}}, \mathrm{C}_{\mathrm{t}}, \log \mathrm{qt}$ and $\log \mathrm{Ct}$.

\begin{tabular}{|lllllll|}
\hline Sl.No. & BentoniteSample No. & \%Removal & $\mathrm{q}_{\mathrm{t}}$ & $\mathrm{C}_{\mathrm{t}}$ & $\log \mathrm{q}_{\mathrm{t}}$ \\
\hline 1 & $\mathrm{~S}_{6}(2540)$ & 90 & 60 & 0.2 & 1.778 & -0.6989 \\
2 & $\mathrm{~S}_{7}(2541)$ & 97.5 & 65 & 0.05 & -1.3010 & -8129 \\
3 & $\mathrm{~S}_{20}(2542)$ & 90 & 60 & 0.2 & 1.7781 & -0.6989 \\
4 & Na Derivative of $\mathrm{S}_{6}(2540)$ & 99 & 66 & 0.02 & 1.8195 \\
5 & Na Derivative of $\mathrm{S}_{7}(2541)$ & 83.65 & 55.77 & 0.327 & 1.6989 \\
\hline
\end{tabular}

Table 8: Percent removal of arsenite with different time intervals.

\begin{tabular}{|lllllll|}
\hline Sl. No. & Bentonite Sample No. & \% Removal & $\mathrm{q}_{\mathrm{t}}$ & $\mathrm{C}_{\mathrm{t}}$ & $\log \mathrm{q}_{\mathrm{t}}$ \\
\hline 1 & $\mathrm{~S}_{6}(2540)$ & 90 & 60 & 0.2 & 1.778 & -0.6989 \\
2 & $\mathrm{~S}_{7}(2541)$ & 97.5 & 65 & 0.05 & -1.3010 \\
3 & $\mathrm{~S}_{20}(2542)$ & 90 & 60 & 0.2 & 1.7781 & -0.6989 \\
4 & Na Derivative of $\mathrm{S}_{6}(2540)$ & 99 & 66 & 0.02 & 1.8195 \\
5 & Na Derivative of $\mathrm{S}_{7}(2541)$ & 83.65 & 55.77 & 0.327 & -1.6989 \\
\hline
\end{tabular}

Table 9: Percent removal of arsenite with different dosage of bentonite for 1 hour.

\begin{tabular}{|llll|}
\hline Sample no & \% Removal for 1 g sample & \% Removal in 2 g sample & \% Removal in 3 g sample \\
\hline $\mathrm{S}_{6}(2540)$ & 85 & 90 & 90 \\
$\mathrm{~S}_{7}(2541)$ & 40 & 70 & 97.5 \\
$\mathrm{~S}_{20}(2542)$ & 70 & 80 & 90 \\
$\mathrm{Na}$ Derivative of $\mathrm{S}_{6}(2540)$ & 58.75 & 80 & 99 \\
$\mathrm{Na}$ Derivative of $\mathrm{S}_{7}(2541)$ & 69.4 & 71.45 & 83.65 \\
\hline
\end{tabular}

different masses of bentonite, e.g. $1 \mathrm{~g}, 2 \mathrm{~g}$ and $3 \mathrm{~g}$ were added to $100 \mathrm{~mL} 2 \mathrm{ppm}$ sodium arsenite solution, it was clear that maximum removal took place when treated with $3 \mathrm{~g}$ bentonite up to 1 hour. The concentration changes to $0.02 \mathrm{ppm}$ from 2 ppm (Table 2). When the efficiency of adsorption of arsenite ion by bentonite minerals was compared with the derivative of the mineral, it had been found that sodium derivative of $\mathrm{S}_{6}$ (2540) had more adsorption capacity in comparison to pure bentonite samples. There were very similar findings in the adsorption capacity of $1 \mathrm{~g}$ bentonite mineral $\mathrm{S}_{7}(2541)$ and its sodium derivative. $3 \mathrm{~g}$ of bentonite sample $S_{7}$ (2541) removed the arsenite ion from $2 \mathrm{ppm}$ to $0.05 \mathrm{ppm}$ in 1 hour, whereas three grams of its sodium derivative removed the arsenite ion concentration from $2 \mathrm{ppm}$ to $0.327 \mathrm{ppm}$. Bentonite sample $\mathrm{S}_{6}$ (2540) has greater efficiency for arsenite removal compared to its sodium derivatives, whereas pure bentonite sample $S_{7}$ (2541) had lesser efficiency than its sodium derivatives for the removal of arsenite ion from aqueous medium up to different time intervals. The percentage removal vs. time with different doses of bentonite shown in Tables 6, 7, 8, 9 and Figs. 1, 3 indicate that the minimum percentage removal is 40 for $\mathrm{S}_{7}(2541)$ and maximum removal is about 99 per cent which takes place with sodium derivative of $S_{6}$ (2540). Effect of contact time and adsorbed amount (Table 10, Fig. 4) has been studied with different grades of pure bentonite samples and their derivatives. A graph of $\log q_{t}$ vs. $\log c_{t}$ values in Fig. 2 (Table
3) showed linearity. The linearity of the graph confirmed the Freundlich isotherm. Fig. 5 (Table 11) show that plot of $c_{t} / q_{t}$ vs. $c_{t}$ is a straight line for the bentonite sample $S_{6}(2540), S_{7}$ (2541), $S_{20}$ (2542) and sodium derivatives of $S_{6}(2540)$ and $S_{7}$ (2541). Fig. 4 showed that first order rate reaction is followed. The straight lines obtained in the graph between ct/qt vs. ct indicate that Langmuir adsorption isotherm is also followed in the case of adsorption in arsenite by bentonites (Fig. 5). The adsorption process may be explained as the arsenite ion on the active sites of the adsorbent and intraparticle diffusion (Li \& Bowman 2001). The adsorption depends on the surface morphology once the surface is covered with the arsenite ions; there is no further scope of adsorption of arsenite from aqueous medium (Chakroborti et al. 2003). The particle size of 300 mesh sieve of bentonites makes available more surface area for adsorption with $3 \mathrm{~g}$ of bentonite.

\section{CONCLUSION}

From different Government reports and tests performed, it is obvious that there is a rapid expansion of arsenic concentration in groundwater in Hazaribagh District of Jharkhand which is a matter of great concern for the inhabitant of that region. Although the impact of arsenic in the human body is slow its effect is dangerous. Government is continuously taking appropriate steps to control the effect of this slow poison. Arsenic removal plants are established in different areas. From the results obtained by different experiments 
Table 10: Variation of the adsorbed amount of arsenite with time.

\begin{tabular}{|llll|}
\hline Sample no & Amount adsorbed in 1 hour & Amount adsorbed in 2 hour & Amount adsorbed in 3 hour \\
\hline $\mathrm{S}_{6}(2540)$ & 1.7 & 1.8 & 1.8 \\
$\mathrm{~S}_{7}(2541)$ & 0.8 & 1.2 & 1.4 \\
$\mathrm{~S}_{20}(2542)$ & 1.4 & 1.6 & 1.7 \\
$\mathrm{Na}$ Derivative of $\mathrm{S}_{6}(2540)$ & 1.175 & 1.263 & 1.6 \\
$\mathrm{Na}$ Derivative of $\mathrm{S}_{7}(2541)$ & 1.388 & 1.477 & 1.587 \\
\hline
\end{tabular}

Table 11: Values of $\left(\mathrm{Ct} / \mathrm{q}_{\mathrm{t}}\right) \mathrm{Vs} \mathrm{C}_{\mathrm{t}}$ for different samples of bentonites.

\begin{tabular}{|lll|}
\hline Sample No. & $\left(\mathrm{Ct} / \mathrm{q}_{\mathrm{t}}\right)$ & $\mathrm{C}_{\mathrm{t}}$ \\
\hline $\mathrm{S}_{6}(2540)$ & 0.001764 & 0.3 \\
$\mathrm{~S}_{7}(2541)$ & 0.015 & 1.2 \\
$\mathrm{~S}_{20}(2542)$ & 0.00428 & 0.6 \\
$\mathrm{Na}$ Derivative of $\mathrm{S}_{6}(2540)$ & 0.00702 & 0.825 \\
$\mathrm{Na}$ Derivative of $\mathrm{S}_{7}(2541)$ & 0.0044 & 0.612 \\
\hline
\end{tabular}

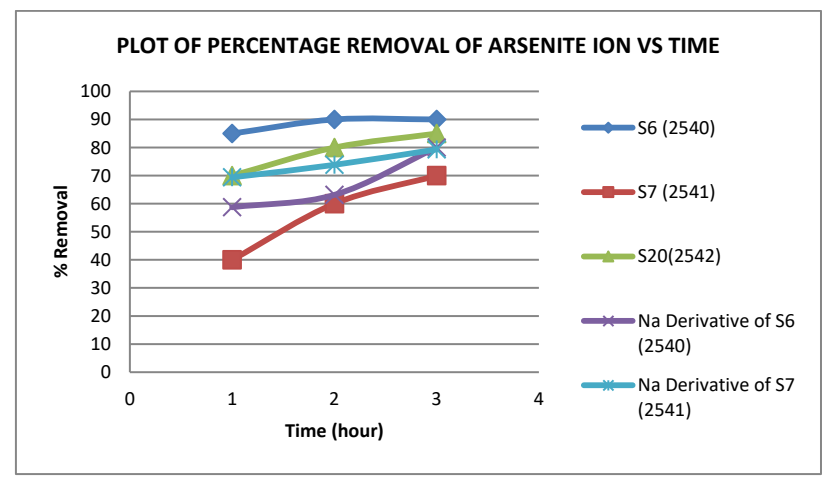

Fig. 1: Effect of contact time on percentage removal.

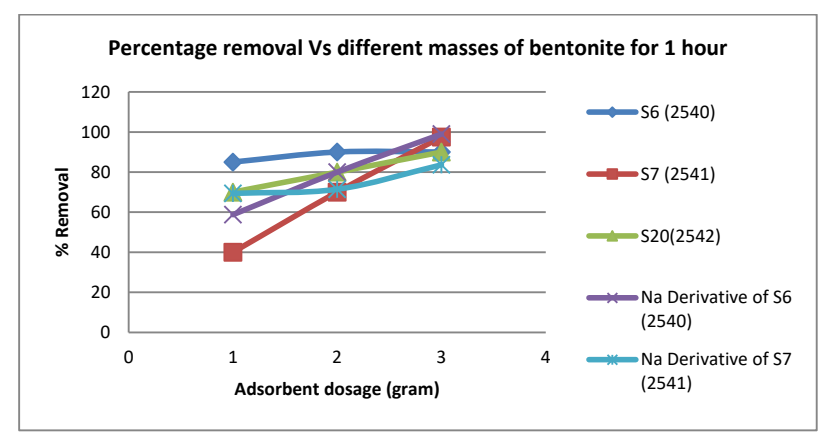

Fig. 3: Effect of dosage on percentage removal.

performed, it is quite clear that bentonite clay and its derivatives especially sodium derivatives are essentially capable for removal of arsenic from water to make it safe for drinking. Bentonites of Hazaribagh may be exploited for removal of arsenite on large by industries also. Both Freundlich and Langmuir adsorption isotherms are followed in case of the removal of arsenite by bentonites.

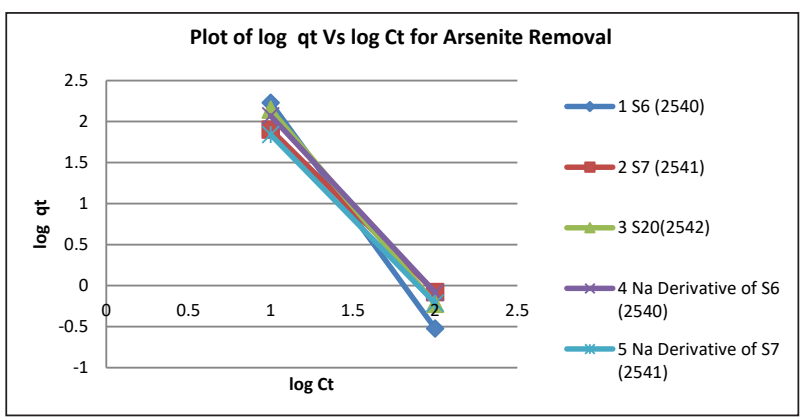

Fig. 2: Freundlich isotherm.

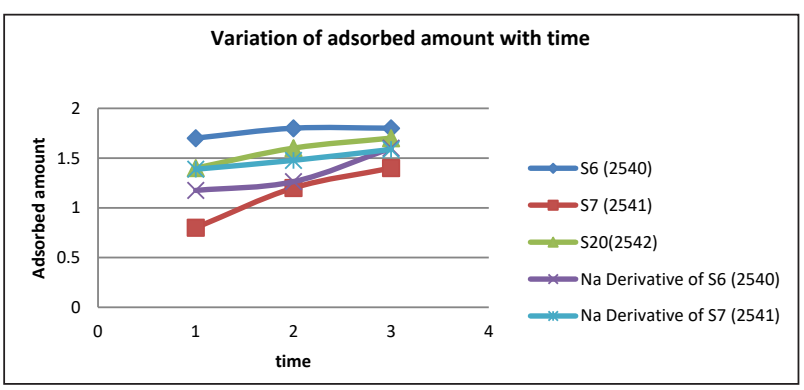

Fig. 4: Plot of variation of the adsorbed amount of arsenite ion with time.

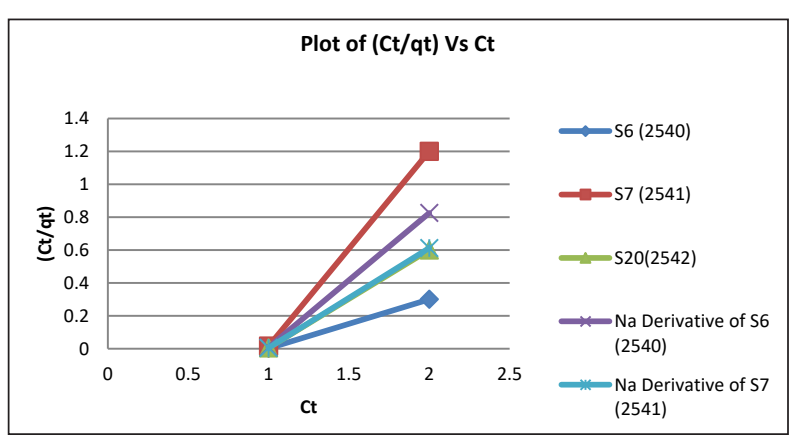

Fig. 5: Langmuir Isotherm.

\section{ACKNOWLEDGEMENTS}

Authors acknowledge the laboratory facility provided by Dr. Usha Sharma of G.B. College, Naugachia.

\section{REFERENCES}

Bailey, S.W. 1982. Crystal structures of clay minerals and their X ray 
identification. In: (Brown, G. ed.) Crystal Structures of Clay Minerals and Their X Ray Identification, pp. 1-123

Brindley, G.W. and Brown 1980. Crystal structure of clay minerals and their $\mathrm{x}$ ray identification. Journal Mineralogical Society, Monographs.

Brindley, G.W., Kao, C.C., Harrison, J.L., Lipsicas, M. and Raythatha, R. 1986. Relation between structural disorder and other characteristics of kaolinites and dickites. Clays and Clay Minerals, 34(3): 239-249.

Calvert, C.S. 1981. Chemistry and mineralogy of iron-substituted kaolinite in natural and synthetic systems (Doctoral dissertation, Texas A\&M University. Libraries), pp 224.

Chakraborti, D., Mukherjee, S.C., Pati, S., Sengupta, M.K., Rahman, M.M., Chowdhury, U.K., Lodh, D., Chanda, C.R., Chakraborti, A.K. and Basu, G.K. 2003. Arsenic groundwater contamination in Middle Ganga Plain, Bihar, India: a future danger?. Environmental Health Perspectives, 111(9): 1194-1201.

Dai, X., Nekrassova, O., Hyde, M.E. and Compton, R.G. 2004. Anodic stripping voltammetry of arsenic (III) using gold nanoparticle-modified electrodes. Analytical Chemistry, 76(19): 5924-5929.

Deliyanni, E.A., Peleka, E.N. and Matis, K.A. 2007. Effect of cationic surfactant on the adsorption of arsenites onto akaganeite nanocrystals. Separation science and Technology, 42(5): 993-1012. Doi: 10.1080/01496390701206306

Ersoy, B. and Çelik, M.S. 2003. Effect of hydrocarbon chain length on adsorption of cationic surfactants onto clinoptilolite. Clays and Clay Minerals, 51(2): 172-180. doi:10.1346/CCMN.2003.0510207

Guyonnet, D., Gaucher, E., Gaboriau, H., Pons, C.H., Clinard, C., Norotte, V. and Didier, G. 2005. Geosynthetic clay liner interaction with leachate: correlation between permeability, microstructure, and surface chemistry. Journal of Geotechnical and Geoenvironmental Engineering, 131(6): 740-749.

Haque, N., Morrison, G., Cano-Aguilera, I. and Gardea-Torresdey, J.L. 2008. Iron-modified light expanded clay aggregates for the removal of arsenic (V) from groundwater. Microchemical Journal, 88(1): 7-13. doi:10.1016/j.microc.2007.08.004

Haron, M.J., Ab Rahim, F., Abdullah, A.H., Hussein, M.Z. and Kassim, A. 2008. Sorption removal of arsenic by cerium-exchanged zeolite P. Materials Science and Engineering: B, 149(2): 204-208. doi:10.1016/j.mseb.2007.11.028

Jha, A.K and Mishra, B. 2012. Removal of fluoride by bentonite minerals of Rajmahal hills. Journal of Indian Chem. Soc., 89: 519.

Jha, A.K. 2012. The Problem of Fluoride, Arsenic and Heavy Metal Contamination in Drinking Water in Ganga Plain, p12, Novelty Company, Patna, ISBN 978-93-81785-14-0

Jha, A.K. 2016. Bentonite minerals and its TGA, DTA, DSC and PXRD studies. Journal Indian Chem. Soc. 93: 437.

Jha, A.K. 2018. Bentonite for chemical industries. Journal J. Indian. Chem. Soc., 95: 35.

Jha, A.K., Jha, A.K., Mishra, A.K., Kumari, V. and Mishra, B. 2011. Softening of hard water by bentonite mineral. Asian Journal of Water, Environment and Pollution, 8(4): 93-96.

Jha, D., Mishra, B.K., Mishra, S.S. and Jha, A.K 2010. Bentonite clays minerals of Rajmahal Hills. J. Haematol. and Ecotoxical., 5(1): 1-7.

Karthikeyan, G., Pius, A. and Alagumuthu, G. 2005. Fluoride adsorption studies of montmorillonite clay. Indian Journal of Chemical Technology, 12: 263-272.

Lagaly, G. 1995. Surface and interlayer reactions: bentonites as adsorbents. In: Churchman, G.J., Fitzpatrick, R.W., Eggleton, R.A. (eds) Clays Controlling the Environment. Proceedings of the 10th international clay conference, Adelaide, Australia. CSIRO Publishing, Melbourne, pp. $137-144$

Li, Z. and Bowman, R.S. 2001. Retention of inorganic oxyanions by organokaolinite. Water Research, 35(16): 3771-3776.

Maiti, A., Das Gupta, S., Basu, J.K. and De, S. 2007. Adsorption of arsenite using natural laterite as adsorbent. Separation and Purification Technology, 55(3): 350-359. doi:10.1016/j.seppur.2007.01.003.

Mermut, A.R. 1994. Layer charge characteristics of 2: 1 silicate clay minerals. CMS workshop lectures. Clay Minerals Society.

Mondal, P., Majumder, C.B. and Mohanty, B. 2006. Laboratory based approaches for arsenic remediation from contaminated water: recent developments. Journal of Hazardous materials, 137(1): 464-479. doi:10.1016/j.jhazmat.2006.02.023

Ramesh, A., Hasegawa, H., Maki, T. and Ueda, K. 2007. Adsorption of inorganic and organic arsenic from aqueous solutions by polymeric Al/Fe modified montmorillonite. Separation and Purification Technology, 56(1): 90-100.

Sharma, P. 1995. Sequential trace determination of arsenic (III) and arsenic (V) by differential pulse polarography. Analytical Sciences, 11(2): 261-262. doi:10.2116/analsci.11.261. 